\title{
Thomé Fang's Pursuit of a Cultural Ideal
}

\author{
Keping $W A N G^{*}$
}

\begin{abstract}
Thomé Fang's philosophical ideas are largely directed to the possibility of a form of humane enculturation that is somewhat similar to the Greek idea of paideia. His persistent pursuit of a cultural ideal is based on the rediscovery of and reflection on the relevance of Chinese and Western heritage, and a comparison of both. As an illustration of the cultural ideal that is the focus of his concern, it is conducive to examine the pagoda allegory that implies an approach to transcultural transformation or synthesis. In practice, this involves a threefold strategy and a reconsideration of cultural origins through artistic features.
\end{abstract}

Keywords: Thomé Fang (Fang Dongmei), humane enculturation, paideia, pagoda allegory, transcultural transformation

\section{Thomé Fangova težnja po kulturnem idealu}

\section{Izvleček}

Thomé Fangove filozofske ideje se večinoma usmerjajo k možnosti človeške kulturalizacije, kar je nekaj podobnega kot grška ideja paideia. Njegova nenehna težnja po kulturnem idealu temelji na ponovnem odkrivanju in razmisleku o pomembnosti kitajske in zahodne dediščine ter na njuni primerjavi. Za ponazoritev kulturnega ideala, Fangove osrednje teme raziskovanja, je tako vredno preučiti alegorijo pagoda, ki pomeni pristop $\mathrm{k}$ transkulturni preobrazbi ali sintezi. $V$ praksi to zahteva trojno strategijo in prevrednotenje kulturnih izvorov skozi umetniške vzorce.

Ključne besede: Thomé Fang (Fang Dongmei), človeška kulturalizacija, paideia, alegorija pagoda, transkulturna preobrazba

Keping WANG (Wang Keping 王柯平) is a senior fellow of the Chinese Academy of Social Sciences (CASS), and emeritus professor of the Philosophy Department of CASS University. His recent publications include Harmonism as an Alternative; Chinese Culture of Intelligence; Reading the Dao: A Thematic Inquiry; Rediscovery of Sino-Hellenic Ideas; Moral Poetics in Plato's Laws (Chinese version); Plato's Poetics in the Republic (Chinese version).

Email address: wangkeping55@163.com

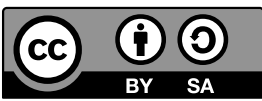


Acknowledged as one of the leading Confucian philosophers in the 20th century, Thomé Fang (Fang Dongmei 方东美, 1899-1977) was among the first to expound and promote the cultural philosophy of Alfred North Whitehead (18611947). As a result of the legacy of the New Culture Movement across China in the early 1920s, he was preoccupied with a sense of mission to renovate Chinese cultural heritage with reference to its Western counterpart. As regards the conception of culture per se, he gives credit to this argument from Whitehead,

Culture is activity of thought, and receptiveness to beauty and humane feeling [...] What we should aim at producing is men who possess both culture and expert knowledge in some special direction. Their expert knowledge will give them the ground to start from, and their culture will lead them as deep as philosophy and as high as art. (Whitehead 1960,13)

Moreover, Fang shares sympathy with Whitehead's advice to go beyond the ivory-tower mode of bookish education, and encourages college students to step into the open air, expose themselves to classical works and the arts in general, and think over more significant issues in their own right instead of bending over classroom desks and burying themselves in textbooks, being alone all day. In this case, "philosophy" and "art" are given a higher position in the cognitive and aesthetic development of humans as humans, for they lead to the enrichment of human wisdom in the intellectual and artistic domains. According to Kant, wisdom can be briefly defined as the practical use of reason that conforms perfectly with the law. Since only the slightest degree of wisdom can be poured into a man by others, he must bring it forth from himself. The precept for obtaining wisdom contains three leading maxims: 1) think for oneself, 2) think into the place of the other (in communication with human beings), and 3) always think consistently with oneself (Kant 2006, 94-95; 2000, vol. 5: 294). In my opinion, this could be the reason why both Whitehead and Fang place much stress on independent and individual thinking.

Along this line of thought, Fang proceeds to contemplate the task of thinking for oneself by virtue of transcultural transformation and creation alike. All this then leads him to pursue a new cultural ideal and philosophize it in terms of cosmopolitan harmonism. A second reflection on what he considers in this sphere reveals some hidden aspects of his theoretical hypothesis, and also evokes a call to reconsider a possible alternative to transcultural interaction and transformational synthesis by means of a threefold process strategy. Moreover, as art is the most celebrated part of each culture, Fang proposes art education as both a starting and pivotal point, based on which it is possible to explore transcultural factors in the cultural origins of the art in question. 


\section{The Cultural Ideal in Allegorical Depiction}

In most of Fang's writings the notion of a cultural ideal is a predominant concern. It can be seen as a form of humane enculturation (ren wen hua cheng 人文 化成), which in Chinese tradition means the activity of gaining enlightenment through culture or the cultural illumination of humanity, which pertains teleologically to a process of accomplishing a fine personality. In fact, Fang deliberately links culture with education, which can be perceived in light of the ancient Greek term paideia, which is a kind of pedagogical operation that enables the young to grow and develop into fully formed and realized beings or citizens. Coincidentally, it involves an interwoven connection between culture and education, and therefore indicates the essential function of both culture and education according to the specific context of this term in the modern Greek language. As noticed in Fang's clarifications, culture and education seem to be two sides of the same coin, closely interrelated to the extent that they walk hand-in-hand as twins in his thinking.

As seen in his essay on "Education and Culture" (1993), for instance, Fang starts with an observation from Alfred Whitehead about the primary objective of university education, as follows: "During the school period the student has been mentally bending over his desk; at the university he should stand up and look around"(Whitehead 1960,37). By so doing, the student will be able to apprehend that correct education is intended to facilitate real intellectual development, nourish the human virtues within, and bring into full play his natural gifts or potential talents. Consequently, the well-educated person will be capable of creating wonders in scholarship and contributing more to his nation, the world and humankind as a whole. If the university as an institution has really fulfilled this mission, it can be considered to have provided education for humankind, and accordingly the educated people will be freed from many problems in terms of pedagogical, social, psychological and other issues. But in Fang's eyes, the practice of education is nowadays often confronted with the issue of problematic man, particularly in the case of young people (Fang 1993a, 12ff). This is mostly due to the expansion of irrational desires that are liable to transform the problematic man into an irrational beast, according to the in-depth Freudian psychoanalysis. For this reason, Fang calls for the development of a higher form of psychology in order to enhance moral science and overcome the lopsided advancement of physical science. He himself draws a blueprint of the cultural ideal in anthropological terms, one that is morally based and spiritually oriented in light of humane enculturation. It consists of nine realms that are metaphorically equivalent to a nine-storied pagoda with a Gothic steeple overhead. 
The pagoda allegory is hierarchical in principle, but structurally organic and interactive due to its step-by-step uplifting of the soul or the progressive cultivation of personality. In brief, it begins with the Homo Faber who basically acts at a natural level and lives in the sphere of physical existence. What comes next as a better substitute is the Homo Dionysiacus, who tends to act in a manic way and puts his life in destructive jeopardy. Therefore, he should be enculturated into the Homo Creator, who usually acts creatively and looks forward to a higher realm of meaning. In Fang's terminology, the Homo Dionysiacus is mingled with the Homo Creator and thus produces the Homo Sapiens with sound learning and wisdom. By contrast, the Homo Faber remains in the sphere of physical existence, the combination of Homo Dionysiacus with Homo Creator enters into the sphere of humane life, and the Homo Sapiens settles down in the sphere of intellectual life. At this stage, the Homo Sapiens emphasizes the performance of reason or rationality, by virtue of which he works to formulate varied systems of knowledge. He thus frees himself from all instinctive drive and blind deeds, and approaches the so-called truth world with rational consideration and guidance. In other words, he will base his life upon the truth world (Fang 1993b, 615; see also Fang 1970; 1972.). Relatively speaking, these three realms comprise a kind of Natural Personality (zi ran ren 自然人), one that is assumed to feature a healthy body, vital energy and rich knowledge, capable of building up a natural world sustained by a scientific culture of universality so often eulogized in the 20th century. Nevertheless, the natural world as such is only one-sided, owing to its being obsessed with scientific culture while neglecting philosophical culture (Fang 1993a, 615).

In order to secure a balance in this context, Fang proposes a scheme of exalting the Natural Personality into the Transcendent Personality (xing shang ren 形上 人). Herein, the former is attributed to the Natural World of physical existence guided by social progression, whereas the latter is attributed to the Spiritual World of transcendent life based on cultural sublimation. On this point, Fang borrows a term from Ernst Cassirer, and claims that the Homo Sapiens needs to be cultivated into the Homo Symbolicus, the man as the operator of symbols who is able to discover and experience the mysteries in the artistic realm. This realm is by no means a representation of the perfect, as it lies in the expression of both the beautiful and ugly, and subjects itself to individual sentimentality as well as volition. It therefore follows that the Homo Symbolicus calls for a higher enculturation in order to exalt himself into the Homo Honaestatis, the man of fine virtue or morality who transcends the artistic realm and nurtures the ethical realm along with "sage-like characteristics" (sheng zhe qi xiang 圣者气象). This facilitates the becoming of a perfect man or whole being (quan ren 全人), who integrates the natural, artistic and moral aspects of personality into a complete whole. Being such a perfected 
man, his life is fulfilled and expanded to the extent that it can accommodate and influence the entire world, and his ability is displayed as outstanding and omnipotent. When his perfection is spiritually sublimated into the Divine World, it will give rise to the Homo Religiosus who is regarded as the God-man, or the co-creator with the divine. As such, Fang's idea seemingly claims that the final step in being humane is to be divine. Analogously speaking, the Homo Religiosus is equal to the Homo Nobilis standing on the top of the pagoda, and often compared to the Confucian ideal of the Sagely Man, the Taoist ideal of the Perfected Man, and the Buddhist ideal of the Enlightened Buddha.

At this point the structure of the pagoda seems completed, but there is still a coping stone overhead. Above this stone stands the Gothic steeple turning upwards to the invisible height of Heaven, and signifying the infinity of the cosmic truth and the endless cultivation of the perfected personality. It leads further to the possible becoming of the Divinity, and the highest realm of mysteriously mysterious experience of the Deus Absconditus. These last two realms of spiritualization overlap to a notable degree. They are, in their essence, symbolic of the supreme power and mysterious mystery of religious divineness, which can be merely imagined and thought a priori. The deployment of them on this occasion is of "importance, value, and ideal beyond the actual", just like Whitehead conceives Deity to be "that factor in the universe" due to its necessary presence as such. For

it is by reference of the spatial immediacies to the ideals of Deity that the sense of worth beyond ourselves arises. The unity of a transcendent universe, and the multiplicity of realized actualities, both enter into our experience by this sense of Deity. Apart from this sense of transcendent worth, the otherness of reality would not enter into our consciousness. There must be value beyond ourselves. Otherwise, every single thing experienced would be merely a barren detail in our own solipsist mode of existence. We owe to the sense of Deity the obviousness of the many actualities of the world, and the obviousness of the unity of the world for the preservation of the values realized and for the transition to ideals beyond realized fact. (Whitehead 1956, 140)

In short, this argument claims that man cannot live by bread alone. In spite of its religious bent, it seems to me more convincing and significant than any other rhetoric or preaching of a personified God. Its emphasis on the sense of Deity will perhaps elicit an awareness of transcendent worth beyond the actual and the finite in human existence. 


\section{A Transcultural View of the Overman}

A question thus arises regarding the cultural ideal mentioned above. That is, among all the existent cultures, is there anything approximate to this ideal? To Fang's mind, there is nothing ready-made in this case, but there are desirable components available in three cultural patterns, namely the ancient Greek, modern European, and traditional Chinese. These patterns are represented in the domains of religion, philosophy and art, for it is in these that the permanent ethos and main current of each culture are embodied and sedimented from a historical point of view.

Take philosophy for example. It is derived from its investigation of the causal interactions between feeling and reason (qing $l i$ 情理), attempting to expose the possible origin, truth and subtlety alike of such phenomena, and leading to the development of insightful wisdom. According to Fang's observation, the Greeks would employ nous (reason and intellect) to illuminate aletheia (truth and reality), and thus develop the truth-directed wisdom; the Europeans would use practical means to meet varied occasions, and thus develop the convenience-oriented technology; and the Chinese would utilize subtle intuition to see through the secret of transformation, and thus develop the parallel-featured wisdom by employing truth-directed wisdom and operating convenience-oriented technology. Accordingly, the seed of Greek wisdom came out of naming objects in logos and thinking over aletheia; the seed of European wisdom came out of seeking power for industrial interest and increasing capacity in order to improve performance; the seed of Chinese wisdom came out of loving to assist all things grow and striving for an intuitively subtle enlightenment (Fang 1993c, 87). By contrast, Greek wisdom evolved into a culture that worships reason with a focus on the justification of aletheia through nous, the European wisdom into a capacity-worshipping culture with a focus on driving sentiment into grotesque imagination, and the Chinese wisdom into a subtlety-directed culture with a focus on returning to primordial harmony via poetic intuition. Hence, in more specific terms, the life of the Greeks could be characteristically represented through three types of spirit, including the Dionysian in favour of passion, the Apollonian in favour of reason, and the Olympian as a result of belittled reason and decreased passion. Among these three, the Apollonian is granted the leading role. When it comes to the life of the $\mathrm{Eu}-$ ropeans, it is chiefly demonstrated through three types of spirit, including the Renaissance, the Baroque, and the Rococo. The Renaissance reveals the appealing power of artistic enthusiasm, the Baroque profound reasoning via science, and the Rococo the ambivalence between reason and feeling. What brings these three into an integrated one is the Faustian spirit. As for the life of the Chinese people, it is 
expressed together in the thoughts of Laozi, Confucius and Mozi. The thought of Laozi explicates the subtle function of the primordial Dao (yuan dao 原道), the thought of Confucius formulates the principle of reciprocal love (ren li 仁理), and the thought of Mozi elaborates the value of extensive love (jian ai 兼爱). Thus correspondingly, the formation of Greek psychology consists of a tripartite mode of three elements. These are the rational, the spirited and the appetite, among which the rational is encouraged to take the lead for the fostering of temperance, while the spirited works in support for the controlling of the appetite. Hence, an ideal personality is dependent on the harmonization of the three parts. Then, the formation of the European psychology bears some features of the double character typified by the Faustian pursuit and the Mephistophelian temptation. Even though these two dimensions remain internally contradictive, they are dynamically interactive, transformational and non-exhaustive. As for the formation of the Chinese mentality, it is composed of a triad of the Human, Heaven and Earth as three shareholders of the universe. In order to form this triad in a constructive sense, a person is expected to enculturate his soul, fulfil his nature, pursue the Dao of sageliness within and kingliness without (nei sheng wai wang 内圣外王), help all things transform and grow, and approach the state of being in Heaven-Human oneness. All this is assumed to be conducive to self-perfection along with supreme morality (Fang 1993c, 90-93).

Nevertheless, everything has two sides, and similarly, each of the three cultural paradigms has its own merits and demerits. Speaking in general terms, the Greek culture is reason-based, truth-worshipping and justice-oriented; therefore, the Greeks are able to perceive the knowledge of the minute, understand the order of the universe, appreciate the beauty of the sublime, and pursue ontologically the Being of all beings. In short, they are concerned not merely with what a thing is, but with how and why it is. They have thus embraced radical intellectualism, and gone to extremes by using knowledge as the one and only measurement to judge cosmic reality, analyse social structures and calculate human virtue. This has then brought forth the over-expansion of reason but the decline of feeling. Since reason keeps running about without being preserved and sustained by feeling, it has become divided and gradually shrunk into a withering entity. Eventually, Greek culture came to an end, its philosophy declined, and its polis collapsed (ibid., 94-96).

As regards the modern European culture, it is convenience-centred and for this reason it worships power, might and right. Its belief in knowledge as power is reflected in the sense of Faustian dissatisfaction. Hence, Europeans tend to be so engrossed in their endless pursuit of knowledge, seeming to be lost in it and never to return. They probe into the bottom of things, dig up the deepest depth for the 
real reality, and even play a game with knowledge by mere logos or boundless imagination. This being the case, European philosophy turns out to be more analytical but less integrative, apart from being mixed up with dichotomy, scepticism and even nihilism, which will in turn cause more problems with hyper-rationalization, internal contradiction, spiritual illusion, etc. Noticeably, what is seemingly laid bare herein is an apparent tendency to manoeuvre a strategy of essentialism to this specific case. By so doing, European philosophy tends to take partial essence for true essence that is, according to the traditional Aristotelian understanding of essence, most irreducible, unchanging, and therefore, constitutive of a person or thing (Fuss 1989, 2). However, the act of applying essentialism to comparative studies most likely leads to either over-generalized or over-simplified arguments, not to speak of somewhat arbitrary and even far-fetched conclusions in certain cases. Such phenomena have occurred as an attestation of the negative effect of "Essentialism One" (Atabaki 2003, 7-8). In this regard, essentialism may be more intractable and more irrecuperable than we thought; it may be essential to our thinking while at the same time there is nothing "quintessential" about it. Yet, a risk of essence may have to be taken because to follow European philosophy is to act as if essentialism has an essence (Fuss 1989, 21). This sceptical observation turns out to be somewhat valid when applied to the practical and periodical condition of essentialism in China.

In brief, such a tendency to exercise essentialism was overriding among certain Chinese thinkers during the first half of the 20th century for three key reasons. Methodologically, essentialist explorations were widely employed rather than critically checked, for they were assumed to help the practitioners get hold of the essential determinants of heterogeneous cultures and philosophies. Ideologically, when confronted with a national crisis for survival because of humiliating defeats and invasions by foreign powers, it was the first priority of all to seek any possible alternatives to innovate China's culture, institutional system and even political governance. Hence there arose an intellectual haste to reconsider Western culture, mainly composed of Greek and modern European traditions, from the standpoint of essentialism against the socio-political background of the old China. Psychologically, essentialism was taken as a quick remedy to find out the essential symptoms and features of both endogenous and alien cultures, and also to take a command of the essence as the very gist of them for the sake of transcultural reform. By so doing, it would be possible, if not very feasible, to reconstruct a new culture with reference to the transcultural ideals, values, and positions selected. This can in fact be seen in the framework of Fang's thinking or philosophizing, and the same is true for many other Chinese thinkers living through similar experiences during the same years. As luck would have it, this framework also turns 
out to be thought-provoking and influential due to its historical effectiveness under special circumstances, albeit with certain shortcomings hidden in the lack of more scientific verifications.

Now let us turn to traditional Chinese culture. In contrast to its Western counterpart it is more morality-based and humanity-oriented. To Fang's mind, it feels a strong affinity for a fair balance between reason and feeling, righteousness and profit, and at the same time it values the oneness between Heaven and the $\mathrm{Hu}-$ man or the Heavenly Dao and the Human Dao. It pays more attention to the importance of such matters as human life (sheng ming 生命), reciprocal love (ren ai 仁爱), transformational and generating energy ( primordial harmony, mean-directed harmonization (zhong he 中和), an analogical approach to understanding the entire category through a single example, and so on. But owing to the long tradition of the centralized social structure, Chinese scholarship culture is usually confined to bureaucratic control and the powerful few. This prevents its pragmatic wisdom from spreading far, and obstructs the successive advancement and wider application of its inventions. On certain occasions in this social setting, the truth is regulated by the so-called authority, the mind is corrupted by vanity and name-dropping, freedom is governed by the ruling class, and creative thinking is strangled by the politically imposed ideology. In order to evade this tension and retain intellectual joy, most Chinese philosophers tend to attach their ideas to artistic fantasy as well as moral cultivation for the sake of their own appreciative contemplation and preservation of the bodysoul. Worse still, they usually walk on the same beaten tracks as their teachers or predecessors, and conform with the old habits and doctrines at the cost of their initiative to seek after the new and the true. Their discourse would thus be rather conventional instead of individual, implicit instead of explicit, suggestive instead of straight-forward, and even absurdly obscure to the extent that the real arguments are covered up in a mist of poetic images or hidden allusions from classical texts. All this leaves an impression that many Chinese philosophers lack the courage to explore the truth, hesitate to get to the bottom of the things concerned, and fail to examine both the beginning and the end in a more logical system (Fang 1993c, 99-103).

According to Thomé Fang, the three cultures described above are complementary to one another in at least two modes, those of redemption by self (zi jiu 自救) and help by other (tazhu 他助). In the former case, the Greeks may go ahead to clarify aletheia with nous and logos as they usually do, but they should not make light of human life; the Europeans may confront things with their convenience-oriented cunning, as they often do, but they should not plunge themselves into absurdity or fantasy; the Chinese may hanker after the knowledge of transformational powers 
with subtle apprehension, but they should not slip into superficiality. Then, in the latter case, the Greek way of abandoning the world so rashly may help modify the European way of living in cunning and fantasy; the European way of using power for varied purposes may help modify the Chinese way of treasuring and preserving life alone to an excessive degree; in return, the Chinese way of appreciating superficially the empty or imagined state of being may help modify the Greek way of worshiping substantial appropriateness, and the European way of applying cunning in all things.

In short, Fang tries to read a new message into the Nietzschean conception of the Overman (Übermensch). Therein, he attempts to strip the Overman off its empty and strange transfiguration, and reconstruct it into an ideal personality by introducing a transcultural transformation. That is, he attempts to remould it by means of three rich forms of wisdom in ancient Greek, modern European and traditional Chinese cultures. In Fang's terminology, one who will be able to get over the Greek weaknesses will become an outstanding European or Chinese individual; one who will be able to overcome the European weaknesses will become a fine Chinese or Greek individual; and one who will be able to transcend the Chinese weaknesses will become an excellent Greek or European individual. That is to say, one who is able to synthesize all the virtues of the Greek, European and Chinese cultures will be likely to become the Overman of an ideal type (Fang 1993c, 105-6). All this shows a harmonious synthesis (he he 和合) of transcultural transformation. Ostensibly, such a synthesis is conducted in the meaningful selection of complimentary ingredients from different sources. The methodological implication it carries is deeply rooted in the mentality of Chinese thinkers. Additionally, the solution Fang proposes is good natured in that it contains a considerable relevance to cosmopolitan harmonism, a harmonism that calls for a deconstruction of cultural boundaries, since it relies on transcultural integration proper. It features a global concern along with a Chinese vision. Actually, in Fang's transcultural preoccupation, what is taken into due account is the common good for humankind as a whole. But this is not supposed to weaken his sensibility to the fact that the Chinese culture needs to be reconstructed with reference to its Greek and European counterparts so long as it is intended to advance and contribute more to both the nation and humankind alike. Only by so doing, in Fang's belief, can such a noble telos be fulfilled. Another thing worth noting is Fang's super-cultural ambition. It is clear that he passionately advises his fellow citizens to go beyond regional and traditional constraints, and redouble their efforts for a transcultural transformation in a creative mode. In order to spur their confidence and enthusiasm, he makes a particular reference to ancient Athens, "the school of Hellas", as a historical model. Even though it was geographically small and 
limited, it became culturally large and essentially unlimited with respect to its influence (ibid., 634). ${ }^{1}$ Incidentally, it occurs to me at this point that the historical model given ought to be grounded on a healthy instead of corrupt democracy because of the bitter lessons Athens had suffered. Such lessons are shown through Plato's critiques of bad politics in the Republic and the Laws. They serve to attest that any models, no matter how appealing and ideal they may be, would be apt to go to the dogs when plunged into a bad framework of politeia as political institution applied to any community.

\section{A Second Reflection and a Threefold Process}

If we make a second reflection on the pagoda allegory with reference to Fang's blueprint of the human and cosmos in the ideal culture in question, we will find several points noteworthy. First and foremost, the allegory implies an ontological hypothesis. The six kinds of personality ranging from the Homo Faber up to the Homo Religiosus represent six realms of being. As is depicted in Fang's terminology, the Homo Faber corresponds to the sphere of physical existence (wu zhi shi jie 物质世界), the Homo Dionysiacus-Creator to the sphere of life (sheng ming shi jie 生命世界), the Homo Sapiens to the sphere of the soul or psychical realm (xin ling shi jie 心灵世界), the Homo Symbolicus to the artistic realm (yi shu shi jie 艺术 世界), the Homo Honestatis to the moral realm (dao de shi jie 道德世界), and the Homo Religiosus to the religious realm (zong jiao shi jie 宗教世界). In comparative language, the former three spheres are within the Natural World of universality largely based on scientific culture, whereas the latter three realms are within the Spiritual World of transcendence mainly based on philosophical culture. In a separate sense, each of them suggests a state of being and a quality of life. In an integrative sense, they manifest a hierarchy of levels or alternatives among which one can choose for one's own personal development. What one can become and what life one expects to live all depends on the choices and efforts one makes.

Secondly, the Homo Nobilis serves as a special bridge between the human and divine. Downward it is appealing to humane enculturation while upward it is motivating the continuous sublimation of the soul from the finite to the infinite. It will then procure the spiritual pursuit of absolute freedom and independent

1 His statement is translated as follows: "We have a population of over ten million living on the Island of Taiwan. We can do what the ancient Greeks had done before in order to develop a small polis with a small population into a culturally great state. This being the case, we can do our best to build up a centre of spiritual culture hereupon so long as we attain a high awareness, set up a truth standard, bring forth a value ideal, and work altogether to upgrade the meaning and worth of life step by step." 
personality. It can be perceived as a cosmic state of being similar to the experience of Heaven-Human oneness. Up here in a metaphorical sense, one will be well in the position to "drive on the cloud and air, ride upon the sun and moon, and roam about freely beyond the four oceans" according to Zhuangzi's assumption (Zhuangzi 1999, 35). This may pave the path for the Homo Nobilis to climb up ultimately to the Divinity and the Deus Absconditus (shen ming 神明).

Thirdly, the blueprint involves a two-way orientation: on the one hand, it ascends to the highest realm of mysterious experience via the organic process of humane enculturation, and on the other, it descends to the sphere of physical existence through the generating power of infinite cosmic spirit. When engaged in this two-way activity, the mere man strives upward to mingle with the cosmic spirit, whereas the cosmic spirit comes downward to transfuse itself into the mere man. Under such circumstances, the "constitution of man" will be filled with the "constitution of divine", and the natural being will be transformed into a religious or spiritual being. That is to say, the person will be qualified not only to act as much as the Homo Sapiens does, but also to act as much as the Divinity does. The purpose of this action is not simply to improve personal cultivation, but upgrade the value of the entire world. As an artist, for example, an individual is "in the capacity not merely of man but in the capacity of the cosmic creator". He can create a great artwork of first rate and "come in ingress into the world as a whole". The beauty of this artwork is just like that of a blooming flower due to its receptiveness to the mystic power of sunlight or "the universal presence of the Spirit in the natural world". It is for this reason that man can experience and feel inwardly the sacred significance hidden mysteriously in all things around him. In addition, it somewhat justifies the qualification of the superior man who is in a Confucian sense possessed of the most complete sincerity, and also facilitates the full development of human nature and the natures of all things alike (jin xing 尽性). Hence, the man of this kind can assist the transforming and nourishing powers of Heaven and Earth (bua yu 化育), and may eventually form a triad with Heaven and Earth (yu tian di can 与天地参) (Zhong yong 1992, VI: 5). All this indicates at least an important mission of human obligation and a high position of humankind in the cosmos or universe, which leads allegedly to the ultimate realm of heaven-human oneness.

Last but not the least, Fang argues that the cosmic spirit sounds abstract, but has concrete effect when it is transfused into any living creatures or existents. It is more or less equal to the Neo-Platonist notion of the Great One as the highest Nous of the universe permeating into the hierarchical forms of life or states of being. It is like a giant water gate, and when it opens it flows into every field and downward to the lowest place. Its power comes from above (Fang 1993b, 632). 
But in my personal observation, this is no more than a poetic depiction. For any downward flow of the Heavenly Way (tian dao xia guan 天道下贯) is based on a subjective assumption rather than objective justification. This is also true of Fang's claim of the two-way orientation. In practice, it is merely through the cognitive faculty and humane enculturation that the upward move through studious learning from the low to high realm (xia xue shang da 下学上达) is rendered possible in the case of spiritual nourishment and personal development. As for the Heavenly Way itself, it is akin to the Chinese view of the cosmic spirit, which is meant to be a kind of super-moral guiding rope to uplift the human soul from low to high. It is therefore deployed as the spiritual pillar of the human condition and the determinant force of human destiny. When the downward flow meets the upward move, human fulfilment is achieved, and the Heavenly Way (tian dao 天道 is transfigured into the Human Way (ren dao 人道).

As stated in The Doctrine of the Mean,

What Heaven (tian 天) has conferred to humans is called natural temperament (xing 性); all that is acting in accord with this temperament is called the Way (dao 道); the approach to helping one know the Way is called education (jiao 教). (Zhong yong 1992, I) ${ }^{2}$

In many cases, those who recommend the downward flow tend to find from something to support their argument in this statement. Yet, when looking closely into the logical order of the four categories, including Heaven, natural temperament, the Way and teaching, we may discover that the Way (dao 道) as the medium is most important of all. That is why it is said "not to be left for an instant. Otherwise, it would not be the Way anymore" (Zhong yong 1992, I). ${ }^{3}$ Then, the knowing of the Way depends on education that is intended to awaken through human culture the good conscience within the individual self. On this point, one will be able to act in accord with the Way, and follow the natural temperament as one's nature of purity and simplicity, as allegedly conferred by Heaven. The practical sequence in this process is then corresponding to what Mencius argues, i.e.,

He who has exhausted all his mental constitution knows his nature. Knowing his nature, he knows Heaven. To preserve one's mental

2 The translation is modified. Cf. The Doctrine of the Mean (Zhong yong), in The Four Books (trans. James Legge). Legge's translation follows: "What Heaven has conferred is called the nature; an accordance with this nature is called the path of duty; the regulation of this path is called instruction."

3 The translation is modified. Cf. The Doctrine of the Mean (Zhong yong), in The Four Books (trans. James Legge). Legge's translation follows: "The path may not be left for an instant. If it could be left, it would not be the path." 
constitution, and nourish one's nature, is the way to serve Heaven. When neither a premature death nor long life causes a man any double mindedness, but he waits in the cultivation of his personal character in whatever issue, this is the way in which he establishes his Heaven-ordained being. (Mencius 1992, 13: 1)

Quite naturally, "the mental constitution" is most determinant and fundamental. It is enculturated and developed to the extent that it becomes what it could be, coming to know one's nature and Heaven, and eventually able to serve Heaven and locate one's Heaven-ordained being. This explains the fact that mental constitution or mind-heart ( $x$ in 心) is guided and nurtured by virtue of education and enculturation, such that it goes upward to meet Heaven. As is so proved in the Confucian tradition, mind-heart also suggests a good conscience within, and knowledge ( $z h i$ 知) is taken as a special kind possessed by the sage. It is through mind-heart that the purity and innocence of human nature (xing 性) is enlightened and fulfilled; it is through knowledge that the Heavenly Way (tian dao 天道) and Heavenly Virtue (tian de 天德) are apprehended and approached; and thus it is through human good conscience (ren xin 人心) that the cosmic spirit (tian xin 天心) is established. Therefore, the so-called Heavenly Way as well as Heavenly Virtue are actually embodied in the human way and human virtue, and for this reason, the downward flow of the cosmic spirit ought to be reversed, because it is practically facilitated and exerted via the upward move of human good conscience involving a continuous process of personal cultivation or moral enhancement. This can also be detected in some of the writings by Qian $\mathrm{Mu}$ 钱穆. For instance, what he has repeatedly stressed is the argument as such: As usual in human life, one's mind-heart can communicate not only with that of other contemporaries, but also with that of the other ancients, and moreover, with that of the subsequent generations. It would be divine to enable it to communicate with Heaven and Earth. Yet, it is not every human individual who can manage it. It is the human mind-heart that can fulfil it. At this point, the mind-heart becomes divine as well as sagely in kind. In China, all the indigenous religions have no Personal God but a Supreme Lord instead, the Lord that is identified with Heaven and Ancestry. Their teachings of spirituality go so deep into the human mind-heart, and at the same time link it closely with Heaven and Ancestry. They thus ensure that human beings succeed in great enterprises without suffering unexpected losses. All this allegedly enables human beings to grow into sages with profound knowledge, knowledge that helps one interact with the heavenly mind-heart (the cosmic spirit), reach Heavenly Virtue, and obtain an insight into the integrity and sincerity that make up the essential substance of the Human Way (Qian 2006a, 2, 11; see also Qian 2006b, 4; 1985, 198). 
Apart from what is mentioned above, we need to move further and reflect upon Fang's exposition of the three cultures and their leading features. In my opinion, his exposition strikes upon the key point, but turns out to be rather over-generalized and over-simplified in certain cases. His perception of the Greek paradigm, for instance, is mainly derived from a Platonic view, his notion of the modern $\mathrm{Eu}-$ ropean paradigm is chiefly inferred from an industrial and pragmatic position, and his observation on the Chinese paradigm is largely based on Confucianism. As a matter of fact, Hellenic naturalism and sophism, the continental idealism and rationalism, the American pioneering spirit and creative thinking, and the Chinese Taoism and Buddhism all account for a great deal regarding the complex features and rich formations of the three cultures concerned. If these elements are neglected or marginalized, any abstraction or summery of the three cultures in terms of their merits and demerits could hardly be called holistic in a justifiable sense. Corresponding to this line of thought, Fang's hypothetical model of the Overman is inspiring as it is, but again it is conceptually idealized and mechanized.

Apparently, the Overman of this type resembles the ideal personality in the pagoda analogy, and an outcome of transcultural transformation involving the three forms of wisdom in Greek, European and Chinese cultures. Such transformation is associated with three alternatives, termed learning (wen 闻), thinking ( $s i$ 思) and practicing ( $x i u$ 修), which consist of a hierarchical approach to accomplishment and denote three levels of enlightenment. Likened to a river in most cases, the wisdom attained through learning would be shallow, as if it stays at its surface; the wisdom achieved through thinking would be intermediate, as if it hangs around the middle; and the wisdom accomplished through practicing would be profound, as if it enters the depths. In contrast, the wisdom nourished through learning, thinking and practicing altogether in a creative manner would be full and complete in degree, for the three methods are organically interactive and interdependent by nature. A man will obtain little if he engages in practicing without thinking and learning; he will get nowhere if he engages in thinking without learning and practicing; and he will go astray if he engages in learning without thinking and practicing (Fang 1993c, 86). This being true, the three modes should be taken into due consideration and put into actual effect in a well-balanced and consistent manner.

To my mind, the transcultural transformation in this regard is no easy enterprise at all. I therefore assume that, in addition to the combined application of the three alternatives, a threefold-process strategy is desirable at any rate. It commences with the comparative phase of transcultural cognition. In this aspect, there will be a mélange of self-driven motivation, observant perception, authentic experience, and modelling behaviour with a cognitive initiative and reflective conscientiousness. 
What proceeds then is a transcultural comparison by identifying via evaluative judgment of the essential differences, similarities, advantages and disadvantages in order to frame a potentially complimentary interrelationship. More often than not, for instance, we Chinese who have been to the West tend to feel so strongly about its impressive performance of public ethics (gong de 公德) and high awareness of the social environment. Personally, I find this culturally complimentary to the Chinese conduct of private morality (si de 私德) within the family network. Subsequently, when time is ripe, it comes to the empathetic phase of transcultural transpection. At this stage, a person is quite at home not only in his native culture but also in the target culture, and even goes so far as to put himself in the mind of someone else from a heterogenic-cultural community. Thus empathetically, he is able to feel, think, speak and even act correspondingly in the same manner as the other. However, he himself is conscious of his own cultural identity and remains more adaptable on various occasions. Naturally, his actions and reactions will be emotionally reasonable or rationally sensible, and meanwhile justifiable with a moderate balance between feeling and reasoning. In other words, what appeals to the empathy or transpection is not merely determined by personal satisfaction, but also by the common good. All this endows him with more insights into the merits and demerits of both his indigenous culture and its heterogenic counterpart. He will then, with a sense of mission, push on and step forward into the creative phase of transcultural transformation. Right in this phase, he will be able to pinpoint the complimentary fundamentals from both cultures and consider a possible solution to any transcultural transformation. It goes without saying that this transformation is a selective and synthetic process, largely based on the stem of the home culture, and not a complete substitution of one with the other at all. Its accomplishment is rendered possible by means of such factors as theoretical hypothesis, gradual internalization, constructive gradation and even necessary elimination. This is by no means a business deal carried out for quick profit. Instead, it is a long and creative process of interactive experimentation. For example, the improvement of any democratic movement originating from the Western tradition is rather time- and energy-consuming with respect to its localization in culturally different regions or its transplantation in politically authoritarian soils. As evinced in the effective history of recent decades, a quick trial of radical reform is usually short-lived, and turns out to be more destructive than constructive. It is by and large owing to the hard fact as such: more haste, less speed, not to speak of the street-gang politicians who may readily abuse the public concern and embrace an ambition to launch a chaotic revolution for sensational news report, but have no efficient policy prudently designed to put it to an end peacefully and undetrimentally. 
In short, the threefold process is correlative and interdependent, all working in principle to demolish the cultural boundaries, break homoculture-centrism of any kind, and promote the transformational creation par excellence in a cosmopolitan sense. Moreover, it bears a hidden link with Whitehead's notion of the "organic process" that is "proceeding from phase to phase, each phase being the real basis from which its successor proceeds towards the completion of the thing in question" (Whitehead 1929,305). On this account, such completion may be conducive not only to the Whitehead's conception of Beauty as "the mutual adaptation of several factors in an occasion of experience" (Whitehead 1932, 251), but also to the creative Beauty of transcultural harmonization in favour of both the community good and the cosmopolitan good.

\section{Art Education as a Starting and Pivotal Point}

The beautiful in art is most illustrious, expressive and representative of every culture. Like Whitehead, Fang sees to art as the relevant illumination of cultural traits and values. He therefore proposes art education as the starting and pivotal point of transcultural reflection, transformation and even creation due to its aesthetic appeal and cultural worth. The education of this kind begins with transcultural reflection based on the cultural origins involved. This factually corresponds to modern Chinese aesthetics that continues to develop along with a comparative study of aesthetic cultures. Such study focuses more on cultural patterns, social ethos, artistic spirit and aesthetic quality, among other factors. It requires vertical survey and horizontal analysis. Meanwhile, it advises the researcher to be capable of assimilating the historical and modern, reconsidering the native and the non-native, and incorporating his knowledge of literature, history and philosophy into a productive whole.

As noted in many of his works, such as the Three Kinds of Philosophical Wisdom (1993c), Taste of Life and Sense of Beauty (1993d), Poetry and Life (1993e), Boundless and Harmonious Spirit of Life (1993f), A General Perception of Human and Nature in Chinese Culture from the Perspective of Comparative Philosophy (1993g), and The Artistic Spirit of Chinese People (1993h), Fang himself persistently probes into distinctive cultural origins from a transcultural perspective, and demonstrates their respective cultural ideals and aesthetic qualities by means of comparison. He adopts a holistic standpoint and looks into three kinds of wisdom related to ancient Greece, modern Europe, and traditional China. Quite deliberately, he proceeds to demonstrate the thought-ways, lifestyles, national identities, artistic tastes and spiritual concerns of each. 
According to Fang's description, the ancient Greeks were well equipped with the faculties of intelligence that were conducive to the wisdom of reality and produced the culture of rationality. They were therefore liable to pursue and justify truth with the power of reason. Their lifestyle was characterized with three forms of spirit in connection with Dionysus, Apollo, and Olympus, symbolizing passion, reason and lack of emotion, respectively. Among them the Apollonian spirit was regarded as the main influence. The modern Europeans would dedicate themselves to seeking the beneficial momentum that led to the wisdom of convenience and nourished industrial cunning. They therefore developed the culture of worshipping might as right, thus driving emotion and feeling into the status of illusions. Their lifestyle featured three types of ethos as reflected in the Renaissance, the Baroque and the Rococo. The Renaissance was attributed to artistic enthusiasm, the Baroque to scientific enlightenment, and the Rococo to the contradiction between emotion and reason, and all three could be integrated into the Faustian spirit. The traditional Chinese would be obsessed with taking delight in a subtle understanding of nature and change. They would rely on the wisdom of reality, make use of the wisdom of convenience, and accomplish the wisdom of equality. They therefore created a culture of subtleness and naturalness, attempting mainly to control the illusory and return to the sincere.

With respect to what Fang believes, the respective features of the three cultures given above have an impact on their corresponding forms of artistic expression and aesthetic quality. In addition, he claims culture to be both a complete manifestation of the human soul and a sophisticated picture of human life, feeling and reasoning altogether. In order to understand the sense of beauty and aesthetic characteristics pertaining to a national identity, one should bear in mind the particular aspects of a national lifestyle and consider the cosmic view of an entire nation. Relatively speaking, the ancient Greeks and modern Europeans tend to approach the cosmos from a scientific perspective, whereas the traditional Chinese tend to approach it from an artistic one. Hence, there arise different tastes, judgments and expressions, which might be thematically displayed in the following table: 
Table 1: The most perceivable and ostensible features of ancient Greek, modern European, traditional Chinese heritages. (Fang 1993d, 355)

\begin{tabular}{|l|l|l|l|}
\hline Cast & Ancient Greek & Modern European & Traditional Chinese \\
\hline Background & Limited cosmos & Boundless cosmos & Deserted wildness \\
\hline Setting & $\begin{array}{l}\text { The Pantheon in } \\
\text { Athens }\end{array}$ & Gothic church & $\begin{array}{l}\text { Ancient temples in } \\
\text { remote mountains }\end{array}$ \\
\hline $\begin{array}{l}\text { Accessory } \\
\text { scene }\end{array}$ & $\begin{array}{l}\text { Sculpture of naked } \\
\text { body }\end{array}$ & $\begin{array}{l}\text { Oil painting and } \\
\text { musical instrument }\end{array}$ & $\begin{array}{l}\text { Landscape painting } \\
\text { and flowers }\end{array}$ \\
\hline $\begin{array}{l}\text { Subject } \\
\text { matter }\end{array}$ & $\begin{array}{l}\text { Imitating nature and } \\
\text { its objects }\end{array}$ & $\begin{array}{l}\text { Governing nature and } \\
\text { its objects }\end{array}$ & $\begin{array}{l}\text { Following the } \\
\text { Dao and being } \\
\text { unconscious of the } \\
\text { object and the self }\end{array}$ \\
\hline Hero & Apollo & Faust & Poet \\
\hline Acting & Singing eulogy & Dancing & Composing poetry \\
\hline Music & $\begin{array}{l}\text { The seven-stringed } \\
\text { lyre and the harp }\end{array}$ & $\begin{array}{l}\text { The violin and the } \\
\text { piano }\end{array}$ & $\begin{array}{l}\text { The bamboo flute and } \\
\text { the inverted bell }\end{array}$ \\
\hline Situation & $\begin{array}{l}\text { A sunny day after } \\
\text { rainfall }\end{array}$ & $\begin{array}{l}\text { Lightning on a sunny } \\
\text { day }\end{array}$ & $\begin{array}{l}\text { The sound of a flute } \\
\text { in the moonlight }\end{array}$ \\
\hline Scene & Lifelike & Real illusion & Illusionary reality \\
\hline Season & A clear autumn day & $\begin{array}{l}\text { Hot summer and cold } \\
\text { winter }\end{array}$ & Warm spring \\
\hline Mood & $\begin{array}{l}\text { Outward expression } \\
\text { of simplicity and } \\
\text { elegance }\end{array}$ & $\begin{array}{l}\text { Struck by thunder, } \\
\text { shocked and stirred } \\
\text { up }\end{array}$ & $\begin{array}{l}\text { Flower into dream } \\
\text { and relaxation of } \\
\text { mind }\end{array}$ \\
\hline
\end{tabular}

This condensed illustration does not transpose every factor into the brief table, but just offers a sketch of some of the most perceivable and ostensible features of the three heritages concerned. Nevertheless, it goes down to the fundamental roots of each so as to highlight their cultural origins for the sake of contrast. Quite interestingly, it lays bare the cardinal discrepancies and hidden resemblances between the three cultures. Take each "hero" in the table for example. "Apollo" is often viewed as a symbol of Greek mythology from which Greek art, ideal beauty and even philosophical spirit originated during the Hellenic Age. "Faust" is usually conceived of as an image of the European mentality that is aligned not only with a persistent investigation into the unknown, but also with non-stop curiosity about creating something novel. The "poet" is normally seen as a figure of spiritual freedom and rich imagination who is sensitive to the living environment and human condition; he enjoys contemplating the outer universe 
and speaking for the inner world, ready to identify himself with the object while roaming through visible and invisible landscapes. As regards the "music" performance, "the lyre and the harp" are played to produce the lyrical tone and unique harmonia of Ionic and Doric types. "The violin and the piano" are played to demonstrate the grand style and profound theme of a symphony through orchistra. "The flute and the bell" are played to describe the pastoral ambiance of the poetic and the picturesque in particular. In a word, all the listed factors in each heritage are interrelated and interactive in a wider context as an outcome of historical inheritance and innovation.

Comparatively, the Greek origin of art is chiefly associated with its mythology, and tends to be mythical, pantheistic, mimetic and divinely-inspired. The traditional Chinese origin of art is deeply connected with the notion of Heaven-Human oneness, and tends to be picturesque, illusionary, intuitive and morality-based. The modern European origin of art is closely coupled with its philosophy of both empiricism and rationalism, and draws from its religious and scientific traditions, and thus tends to be profound, explorative and truth-oriented in spite of being emotionally expressive.

At this point, Fang himself looks into the interaction between the poetic state in art and the rational interest in science when examining the typical discrepancy between traditional Chinese culture and its Western counterpart. He asserts that science and art do not oppose each other, and they can reach a kind of win-win situation, if not a complementary one. Because the accomplishment of rational interest in science does not violate the fulfilment of the poetic state in art, and vice versa. Since different nations have some different characteristics in national identity and mentality, they are inclined to perceive art and science from different angles and values. All this is largely determined by their distinct worldviews and cosmic outlooks. As to the high and low evaluation of art and science, it varies from one to another as a result of different tastes and judgments on different occasions (Fang 1993d, 366). In my observation, Fang attempts to hold a balanced stance by treating art and science as equally important, for they contribute a great deal to human existence and the quality of life. Any imbalanced preferences and actions are liable to be negative rather than positive in all cases.

Additionally, Fang proceeds to re-examine and reemphasize the weaknesses of ancient Greek, modern European and traditional Chinese heritage as well as their respective strengths. He does so in light of a broader international perspective and higher transcultural awareness. In his opinion, the wisdom of the Greek type had four problematic aspects as embodied in its tendency to abandon reality, eulogize the ideal, deny the body, and favour deities. It is therefore subject to nihilism with 
regard to the human world, and to fantasy with regard to human life, among others. Moreover, this was conducive to the collapse of Greek culture and the decline of its philosophy (Fang 1993c, 96).

The wisdom of the modern European type is over-engrossed in speculative debate and theorization. Accordingly, it led Europeans to become obsessed with intellectual reasoning and detailed analysis. When it comes to dealing with real facts, it tries to demonstrate so-called profundity by covering up the perceived reality, and thus create fantastic ivory-towers by spoiling the wisdom-based aspects of its own traditions. This is reflected in psychoanalysis, which gives much weight to what is assumed to be true in day-dreams and subconscious fantasies. As shown in the process of verification through deductive and inductive reasoning, modern European culture is prone to much scepticism and the like. All this ends up in a dichotomy between mind and body, and a boundary between the inward and the outward (ibid., 99).

Finally, when it comes to looking at the wisdom of Chinese type, Fang claims that it entails the understanding and attainment of the Dao in itself. Even though this tradition is over 4,000 years old or so, it remains opaque rather than clear. One of the reasons for this lies in the thought-ways of Chinese philosophers, which depend upon artistic imagination, moral cultivation, and personal utility for the preservation of the mind and body. More often than not, it is biased towards theories of artistic absurdities and illusions, confined to the habit of ethical malpractice, obscured in the name of in-depth reflections, and attached to self-pleasing preferences. Being self-indulged in artistic reverie, moral compassion and natural humaneness, the Chinese tradition tends to be empathetic with the scene and image, and contrives to evoke a sort of aesthetic feeling all of a sudden. This being the case, it is deprived of the virtue of perseverance shared by scientists that encounters more difficulties in getting to the bottom of things, and such that it grows less active to exercise thorough investigation and critical analysis. It is therefore slow to explore in the ultimate depth both the beginning and the end, such that it falls due to the lack of a logical thinking system (ibid., 103).

Still, Fang goes on to argue about the merits and demerits of the three kinds of wisdom by means of an essentialist approach. What he says mirrors part of what he used to know and think about the three traditions during the New Cultural Movement of the 1920s. Hence it features both overstatement and overgeneralization. Nevertheless, his critical reflections are thought-provoking, as they encourage readers to think twice about the criticisms given, especially about the implied necessity of placing art and science on an equal footing for the sake of cultural innovation in terms of creative transformation. Hence, they serve to 
rebalance the radical modes of self-pleasing preferences, narrow-minded bias, and pleasure-ridden superficiality, among others.

Teleologically, Fang's study of the three cultures attempts to sort out the characteristics of their typical origins in one sense, and strives to facilitate a possible transcendence through transformational creation in another. It is thus pointing to a noble motive to fulfil the mission of upgrading cultural innovation and bettering human life. According to Fang in this regard, if a reasonable stance were taken to assimilate all the virtues of valuable cultures, say to synthesize the cognitive and aesthetic wisdom of the three examined in this study, it would be able to go beyond their limits and enrich their values. Under such circumstances, it would ask for open-mindedness, honesty, sincerity, integrity, creativity and so forth. The socalled Overman in this case should be an ideal personality who would get over the defects of ancient Greeks, modern Europeans and traditional Chinese, all at the same time. He would be adept at pursuing human perfection by absorbing each of their merits and strengths (Fang 1993c, 105-6). To my mind, this assumption is obviously romantic and idealistic. It is also far from being attainable, because it usually resides in mere imagination, if not wishful thinking. Notwithstanding that, it may still shed some light on the context of cultural globalization and glocalization.

\section{Conclusion}

In the final analysis, Thomé Fang's pursuit of the cultural ideal stays open to organic process and transcultural features apart from those related to poetic wisdom and religious expectation. In order to illustrate the hierarchical and progressive model of humane enculturation as the vital part of his cultural ideal, he applies the pagoda allegory with further explication of the distinctive worlds of human becoming and perfection. Notably, his special emphasis on the divine dimension of personal cultivation appears impressive, appealing and metaphysical in theory, but its possibility remains opaque, sceptical or questionable in practice. In this case, the intentional integration of the divine aspect with the moral orientation seems to be more hypothetical than realistic in terms of the overall background or context concerned. This is mainly due to the indigenous and persevering characteristics of Chinese cultural heritage.

For instance, the worship of the Heavenly Way (tian dao 天道) in China cannot be identified with the worship of God in the West. Hypothesized as the highest Mandate of Heaven, it is alleged to descend toward the Human Way (ren dao 人道). More often than not, the former is to be incorporated into the latter and 
to be suspended otherwise. In other words, the former is no more substantial and important than the latter in a moral or practical sense. Still, when compared with the existence of God and other spirits, the morality of personal cultivation is more significant and valid than anything else. It is for this reason that Confucianism remains reluctant to talk about the "odd, puissance, turmoil and deity".

Turning to the Christian tradition, this-world is distinguished from the other-world. God is highly worshiped, and thus believed to help those who help themselves. However, in the Chinese tradition there is no such distinction between this-world and the other-world, and between the secular and the divine, because the one-world view has been prevailing through its cultural history. People usually take it for granted that they should help and rely on themselves in the absence of God. This is largely due to the optimistic spirit of a joy-conscious culture. In practice, the joy-conscious culture makes the national mentality accustomed to take delight in painful suffering, and the optimistic spirit has enabled the Chinese to become what they are, never losing a hope even when confronted with the gravest crises and hardships. Knowing well the difficult condition of human existence sandwiched between Heaven and Earth, they have no other choice but insist on self-reliance under all circumstances. On this account, they seem to bear a larger and heavier cross than the Christians who are exposed to divine assistance and redemption.

In addition, the Chinese majority commit themselves to ancestor worship rather than the worship of God. Being a vital part of folklore, ancestor worship is characteristically quasi-religious under certain conditions. It can be employed to reinforce communal solidarity and social cohesion on the one hand, and to arouse a strong moral sense to honour the family on the other, which will facilitate the self-consciousness of personal cultivation for the sake of self-realization. In order to express and manifest piety and respect to one's ancestors, there are ancestry halls in most of the older and larger villages, instead of Christian or Catholic chapels, across the vast territory of China. All these evidences, among other factors, strike me as an inevitable and formidable hindrance to the fulfilment of Fang's intentional integration, in spite of his engaging exploration of the cultural ideal as is stated in this paper. 


\section{References}

Atabaki, Touraj. 2003. Beyond Essentialism: Who Writes Whose Past in the Middle East and Central Asia? Amsterdam: Aksant, Amersfoort.

Fang, Dongmei 方东美. 1993a. "Jiao yu yu wen hua 教育与文化 (Education and Culture).” In Fang Dongmei xin ru xue lun zhu ji yao 方东美新儒学论著辑 要 (Thomé Fang's Selected Writings on Modern Confucianism), edited by Jiang Guobao, and Zhou Yazhou. Beijing: Zhongguo Guangbo Dianshi Press.

—.1993b. "Zhongguo zhe xue dui wei lai shi jie de ying xiang 中国哲学对未 来世界的影响 (The Impact of Chinese Philosophy on the Future World).” In Fang Dongmei xin ru xue lun zhu ji yao 方东美新儒学论著辑要 (Thomé Fang's Selected Writings on Modern Confucianism), edited by Jiang Guobao, and Zhou Yazhou. Beijing: Zhongguo Guangbo Dianshi Press.

-1993c. “Zhexue san hui 哲学三慧 (Three Kinds of Philosophical Wisdom). In Fang Dongmei xin ru xue lun zhu ji yao 方东美新儒学论著辑要 (Thomé Fang's Selected Writings on Modern Confucianism), edited by Jiang Guobao, and Zhou Yazhou. Beijing: Zhongguo Guangbo Dianshi Press.

—.1993d. “Sheng ming qing diao yu mei gan 生命情调与美感 (Taste of Life and Sense of Beauty)." In Fang Dongmei ji (Selected Works of Thomé Fang), edited by Huang Kejian. Beijing: Qunyan Press.

—. 1993e. "Shi yu sheng ming 诗与生命 (Poetry and Life)." In Fang Dongmei ji 方东美集 (Selected Works of Thomé Fang), edited by Huang Kejian. Beijing: Qunyan Press.

—. 1993f. "Guang da he xie de sheng ming jing shen 广大和谐的生命精神 (Boundless and Harmonious Spirit of Life).” In Fang Dongmei ji 方东美 集 (Selected Works of Thomé Fang), edited by Huang Kejian. Beijing: Qunyan Press.

—.1993g. "Cong bi jiao zhe xue guan kuang guan Zhongguo wen hua li de ren yu ziran 从比较哲学旷观中国文化里的人与自然 (A General Perception of Human and Nature in Chinese Culture from the Perspective of Comparative Philosophy).” In Fang Dongmei ji 方东美集 (Selected Works of Thomé Fang), edited by Huang Kejian. Beijing: Qunyan Press.

- 1993h. "Zhongguo ren de yi hus jing hsen 中国人的艺术精神 (The Artistic Spirit of Chinese People).” In Fang Dongmei ji 方东美集 (Selected Works of Thomé Fang), edited by Huang Kejian. Beijing: Qunyan Press.

Fang, Thomé 方东美. 1970. The Alienation of Man in Religion, Philosophy and Philosophical Antbropology. The Chinese Bureau of Cultural Affairs.

—. 1973. "A Philosophical Glimpse of Man and Nature in Chinese Culture." Journal of Chinese Philosophy 1:3-26. http://www.thomehfang.com. 
Fuss, Diana. 1989. Essentially Speaking: Feminism, Nature and Difference. New York: Routledge.

Kant, Immanuel. 2000. Critique of the Power of Judgment. Translated by Paul Guyer. Cambridge: Cambridge University Press.

- 2006. Anthropology from a Pragmatic Point of View. Translated by Robert Louden. Cambridge: Cambridge University Press.

Mencius. 1992. The Works of Mencius. In The Four Books, translated by James Legge. Changsha: Hunan Press.

Qian, Mu 钱穆. 1985. Kongzi yu lun yu 孔子与论语 (Confucius and the Analects). Taipei: Lianjing Publishing Company.

—. 2006a. Xian dai Zhongguo xue shu lun heng 现代中国学术论衡 (Essays on Modern Chinese Scholarship). Beijing: Sanlian Bookshop.

—. 2006b. Zhongguo si xiang tong su jiang bua 中国思想通俗讲话 (Lectures on Chinese Thought). Beijing: Sanlian Bookshop.

Whitehead, Alfred N. 1929. Process and Reality. Cambridge: Cambridge University Press.

—.1932. Adventures of Ideas. New York: Mentor Books.

—. 1956. Modes of Thought. Cambridge: Cambridge University Press.

—.1960. The Aims of Education. New York: Mentor Books.

Zhong yong 中庸. 1992. The Doctrine of the Mean. In The Four Books, translated by James Legge. Changsha: Hunan Press.

Zhunagzi. 1999. The Zhuangzi, vol. 1. Translated by Wang Rongpei. Beijing: Foreign Languages Press. 